$\begin{array}{cc}\text { ACADEMIA ROMÂNĂ } & \text { Rev. Roum. Chim., } \\ \text { Revue Roumaine de Chimie } & \text { 2020.65(6), 587-593 } \\ \text { http://web.icf.ro/rrch/ } & \text { DOI: 10.33224/rrch.2020.65.6.09 }\end{array}$

\title{
NEW HYPERCOORDINATED ORGANOANTIMONY(V) BROMIDES. SYNTHESIS AND STRUCTURAL CHARACTERIZATION
}

\author{
Eleonora DENES, ${ }^{\mathrm{a}}$ Christian LINDORFER,,${ }^{\mathrm{a}, \mathrm{b}}$ Luiza DRAGOMIR, ${ }^{\mathrm{a}}$ \\ Ciprian I. RAT, ${ }^{\mathrm{a}}$ and Anca SILVESTRU ${ }^{\mathrm{a}, *}$
}

\begin{abstract}
${ }^{a}$ Supramolecular Organic and Organometallic Chemistry Centre (CCSOOM), Chemistry Department, Faculty of Chemistry and Chemical Engineering, "Babeş-Bolyai" University, RO-400028 Cluj-Napoca, Roumania

${ }^{\mathrm{b}}$ On leave of absence from Higher Technical Education Institute (HTBLA), Wels, Austria
\end{abstract}

The oxidative addition of bromine to $\left[2-\left(\mathrm{Me}_{2} \mathrm{NCH}_{2}\right) \mathrm{C}_{6} \mathrm{H}_{4}\right] \mathrm{SbBr}_{2}$ and $\left[2-\left(\mathrm{Me}_{2} \mathrm{NCH}_{2}\right) \mathrm{C}_{6} \mathrm{H}_{4}\right] \mathrm{Ph}_{2} \mathrm{Sb}$ resulted in the new hypercoordinated organoantimony(V) compounds [2- $\left(\mathrm{Me}_{2} \mathrm{NCH}_{2}\right)$ $\left.\mathrm{C}_{6} \mathrm{H}_{4}\right] \mathrm{SbBr}_{4}$ (1) and [2-( $\left.\left.\mathrm{Me}_{2} \mathrm{NCH}_{2}\right) \mathrm{C}_{6} \mathrm{H}_{4}\right] \mathrm{Ph}_{2} \mathrm{SbBr}_{2}$ (2), respectively. The new species were isolated as colourless solids and their solution behaviour was investigated by ${ }^{1} \mathrm{H}$ and ${ }^{13} \mathrm{C}\left\{{ }^{1} \mathrm{H}\right\}$ NMR spectroscopy. Single-crystal X-ray diffraction studies evidenced strong $\mathrm{N} \rightarrow \mathrm{Sb}$ intramolecular interactions in $\mathbf{1}$ and $\mathbf{2}$. While $\mathbf{2}$ has a monomeric structure, in the crystal of $\mathbf{1}$ the molecules are associated in polymeric chains by weak $\mathrm{Br} \cdots \mathrm{H}$ contacts. The ionic derivative $\left[\left\{2-\left(\mathrm{Me}_{2} \mathrm{NH}^{+} \mathrm{CH}_{2}\right) \mathrm{C}_{6} \mathrm{H}_{4}\right\} \mathrm{Ph}_{2} \mathrm{SbBr}_{2}\right] \mathrm{Br}^{-} \cdot \mathrm{CHCl}_{3}\left(3 \cdot \mathrm{CHCl}_{3}\right)$ was isolated as a hydrolysis product during our attempts to grow single-crystals of 2 from a $n$-hexane $/ \mathrm{CHCl}_{3}$ mixture of solvents.

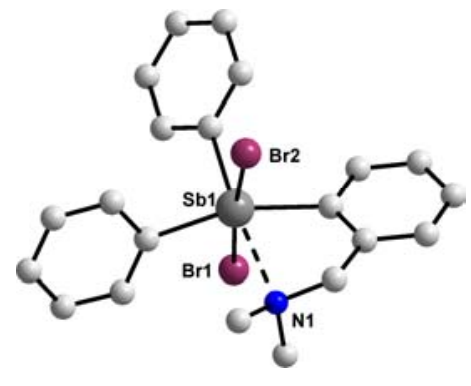

\section{INTRODUCTION}

Organoantimony halides were studied over years in connection with their structural aspects and their use as starting materials for various organoantimony compounds with potential in catalysis, biology and nanomaterials. ${ }^{1}$ For compounds of type $\mathrm{R}_{\mathrm{n}} \mathrm{SbX}_{5-\mathrm{n}}$ $(n=1-4)$ it was observed that the thermal stability decreases with the increase of the number of halogen atoms in the molecule. Similarly with the organoantimony(III) species, the aryl substituted organoantimony $(\mathrm{V})$ derivatives are more stable than those containing alkyl groups. ${ }^{2}$ The stability of organoantimony compounds can be significantly increased by using either bulky organic groups, e.g. $\left[\left(\mathrm{Me}_{3} \mathrm{Si}\right)_{2} \mathrm{CH}\right]_{3} \mathrm{SbBr}_{2},{ }^{3} \quad\left(2-\mathrm{C}_{4} \mathrm{H}_{3} \mathrm{~S}\right)_{3} \mathrm{SbBr}_{2},{ }^{4}$
$\left(\mathrm{C}_{6} \mathrm{H}_{11}\right)_{3} \mathrm{SbBr}_{2},{ }^{5} \quad\left(\mathrm{C}_{6} \mathrm{~F}_{5}\right)_{3} \mathrm{SbBr}_{2},{ }^{6}$ or organic groups bearing donor atoms capable to coordinate intramolecularly to metal. ${ }^{7}$ An increased coordination number at antimony and an increased stability was achieved either by dimerization through halogen bridging atoms, as in biphenyl-2,2'-diylphenylantimony dibromide $\left(\mathrm{C}_{12} \mathrm{H}_{8}\right) \mathrm{PhSbBr}_{2}{ }^{8}$ or by hypercoordination. By contrast with the large number of hypercoordinated antimony(III) compounds with $N, C$-chelating ligands reported during last years, ${ }^{1 a}$ only few antimony $(\mathrm{V})$ species were described till now, e.g. $\mathrm{R}\left(\mathrm{C}_{6} \mathrm{H}_{4} \mathrm{Me}-4\right)_{2} \mathrm{SbCl}_{2} \quad[\mathrm{R}=2$ $\left(\mathrm{Me}_{2} \mathrm{NCH}_{2}\right) \mathrm{C}_{6} \mathrm{H}_{4}, \quad 8-\left(\mathrm{Me}_{2} \mathrm{NCH}_{2}\right) \mathrm{C}_{10} \mathrm{H}_{6}$ or 8-

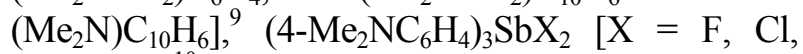
$\mathrm{PhC}(\mathrm{O}) \mathrm{O}],{ }^{10} \quad\left\{\mathrm{MeN}\left(\mathrm{CH}_{2} \mathrm{C}_{6} \mathrm{H}_{4}\right)_{2}\right\}\left(\mathrm{C}_{6} \mathrm{H}_{4} \mathrm{Me}-4\right) \mathrm{SbX}_{2}$ $(\mathrm{X}=\mathrm{F}, \mathrm{Cl}, \mathrm{Br}),{ }^{11} \mathrm{RSbCl}_{4}, \mathrm{R}_{2} \mathrm{PhSbCl}_{2}, \mathrm{RPh}_{2} \mathrm{SbCl}_{2}$ 
$\left[\mathrm{R}=o-\left(\mathrm{CH}=\mathrm{N}-2,6-\mathrm{Pr}_{2}^{\mathrm{i}} \mathrm{C}_{6} \mathrm{H}_{3}\right) \mathrm{C}_{6} \mathrm{H}_{4}\right],{ }^{12}$ as well as the ionic species [ $\left.\left\{\mathrm{MeN}\left(\mathrm{CH}_{2} \mathrm{C}_{6} \mathrm{H}_{4}\right)_{2}\right\}\left(\mathrm{C}_{6} \mathrm{H}_{4} \mathrm{Me}-4\right) \mathrm{SbI}\right]^{+} \mathrm{I}^{-}$, $\left[\left\{\mathrm{MeN}\left(\mathrm{CH}_{2} \mathrm{C}_{6} \mathrm{H}_{4}\right)_{2}\right\}\left(\mathrm{C}_{6} \mathrm{H}_{4} \mathrm{Me}-4\right) \mathrm{SbCl}\right]\left[\mathrm{SbCl}_{6}\right]$ and $\left[\left\{\mathrm{MeN}\left(\mathrm{CH}_{2} \mathrm{C}_{6} \mathrm{H}_{4}\right)_{2}\right\}\left(\mathrm{C}_{6} \mathrm{H}_{4} \mathrm{Me}-4\right) \mathrm{SbBr}\right]\left[\mathrm{BF}_{4}\right] .{ }^{11}$

We have previously reported the synthesis and spectroscopic characterization of several organoantimony (III) halides and pseudohalides of type [2$\left.\left(\mathrm{Me}_{2} \mathrm{NCH}_{2}\right) \mathrm{C}_{6} \mathrm{H}_{4}\right]_{\mathrm{n}} \mathrm{SbX}_{3-\mathrm{n}}\left(\mathrm{n}=1,2 ; \mathrm{X}=\mathrm{Cl}, \mathrm{Br}, \mathrm{I}^{13}\right.$ $\left.\mathrm{X}=\mathrm{SCN}, \mathrm{SeCN}^{14}\right)$, as well as about triorganoantimony(III) compounds of type $\left[2-\left(\mathrm{Me}_{2} \mathrm{NCH}_{2}\right) \mathrm{C}_{6} \mathrm{H}_{4}\right]_{\mathrm{n}}$ $\mathrm{R}_{3-\mathrm{n}} \mathrm{Sb}(\mathrm{n}=1,2 ; \mathrm{R}=\mathrm{Ph}, \mathrm{Mes})^{15}$ and we observed in all cases that the nitrogen atom in the pendant arm of the 2-( $\left(\mathrm{Me}_{2} \mathrm{NCH}_{2}\right) \mathrm{C}_{6} \mathrm{H}_{4}$ group is intramolecularly coordinated to antimony. As a continuation of our studies, we report here about the synthesis and structural characterization of two new organoantimony $(\mathrm{V})$ compounds, namely [2-( $\left.\left.\mathrm{Me}_{2} \mathrm{NCH}_{2}\right) \mathrm{C}_{6} \mathrm{H}_{4}\right]$ $\mathrm{SbBr}_{4}$ (1) and [2-( $\left.\left.\mathrm{Me}_{2} \mathrm{NCH}_{2}\right) \mathrm{C}_{6} \mathrm{H}_{4}\right] \mathrm{Ph}_{2} \mathrm{SbBr}_{2}$ (2). In addition, the crystal structure of the ionic species
$\left[\left\{2-\left(\mathrm{Me}_{2} \mathrm{NH}^{+} \mathrm{CH}_{2}\right) \mathrm{C}_{6} \mathrm{H}_{4}\right\} \mathrm{Ph}_{2} \mathrm{SbBr}_{2}\right] \mathrm{Br}^{-} \cdot \mathrm{CHCl}_{3}$ $\left(3 \cdot \mathrm{CHCl}_{3}\right)$, serendipituously obtained, is also discussed.

\section{RESULTS}

\section{Synthesis}

The organoantimony $(\mathrm{V})$ compounds [2$\left.\left(\mathrm{Me}_{2} \mathrm{NCH}_{2}\right) \mathrm{C}_{6} \mathrm{H}_{4}\right] \mathrm{SbBr}_{4}$ (1) and [2$\left.\left(\mathrm{Me}_{2} \mathrm{NCH}_{2}\right) \mathrm{C}_{6} \mathrm{H}_{4}\right] \mathrm{Ph}_{2} \mathrm{SbBr}_{2}$ (2) were prepared by the oxidative addition of bromine to the corresponding organoantimony (III) starting materials, as depicted in eq. 1 and eq. 2, respectively. The two compounds were isolated as microcrystalline colourless solids, soluble in common organic solvents.

$$
\begin{aligned}
& {\left[2-\left(\mathrm{Me}_{2} \mathrm{NCH}_{2}\right) \mathrm{C}_{6} \mathrm{H}_{4}\right] \mathrm{SbBr}_{2}+\mathrm{Br}_{2} \longrightarrow\left[2-\left(\mathrm{Me}_{2} \mathrm{NCH}_{2}\right) \mathrm{C}_{6} \mathrm{H}_{4}\right] \mathrm{SbBr}_{4}} \\
& \mathbf{1} \\
& {\left[2-\left(\mathrm{Me}_{2} \mathrm{NCH}_{2}\right) \mathrm{C}_{6} \mathrm{H}_{4}\right] \mathrm{Ph}_{2} \mathrm{Sb}+\mathrm{Br}_{2} \longrightarrow\left[2-\left(\mathrm{Me}_{2} \mathrm{NCH}_{2}\right) \mathrm{C}_{6} \mathrm{H}_{4}\right] \mathrm{Ph}_{2} \mathrm{SbBr}_{2}}
\end{aligned}
$$

Compounds 1 and 2 were investigated by ${ }^{1} \mathrm{H}$ and ${ }^{13} \mathrm{C}\left\{{ }^{1} \mathrm{H}\right\}$ NMR spectroscopy in $\mathrm{CDCl}_{3}$ solution. The crystal and molecular structures of $\mathbf{1}$, 2 and of the ionic compound $\mathbf{3} \cdot \mathrm{CHCl}_{3}$ were determined by single-crystal X-ray diffraction. The formation of $\mathbf{3}$ can be explained by the partial hydrolysis of $\mathbf{2}$ in solution followed by the reaction of the resulting $\mathrm{HBr}$ with 2. Selective interatomic distances and bond angles are given in Table 1, while the ellipsoids representations with atom numbering schemes for $\mathbf{1}, \mathbf{2}$ and $\mathbf{3} \cdot \mathrm{CHCl}_{3}$ are shown in Figures 1-3, respectively.

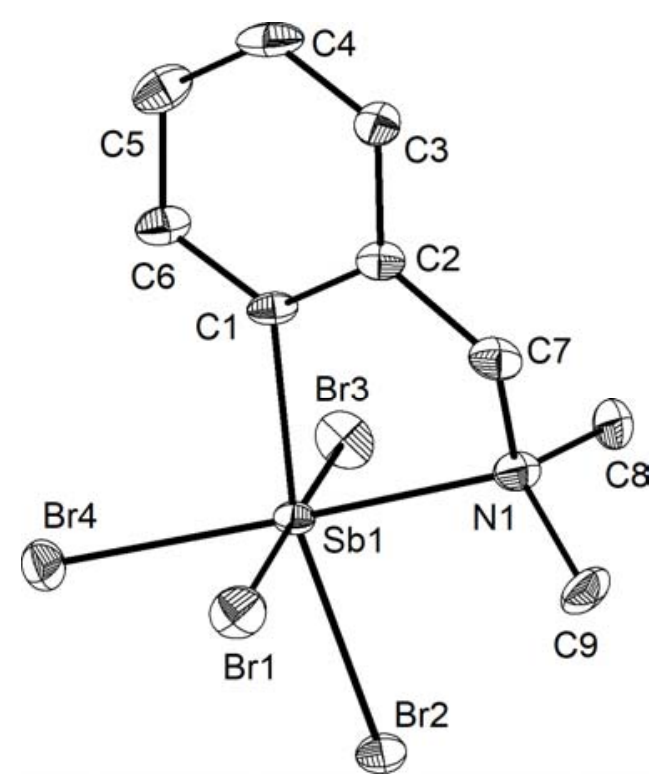

Fig. 1 - Thermal ellipsoids (30\% probability) representation of $S-1$. Hydrogen atoms were omitted for clarity. 
Table 1

Selected interatomic distances $[\AA]$ and bond angles $[\mathrm{deg}]$ in $\mathbf{1}, \mathbf{2}$ and $\mathbf{3} \cdot \mathrm{CHCl}_{3}$

\begin{tabular}{|c|c|c|c|c|c|}
\hline \multicolumn{2}{|c|}{1} & \multicolumn{2}{|c|}{2} & \multicolumn{2}{|c|}{ 3. $\mathrm{CHCl}_{3}$} \\
\hline $\mathrm{Sb}(1)-\mathrm{C}(1)$ & $2.131(8)$ & $\mathrm{Sb}(1)-\mathrm{C}(1)$ & $2.127(4)$ & $\mathrm{Sb}(1)-\mathrm{C}(1)$ & $2.124(6)$ \\
\hline $\mathrm{Sb}(1)-\operatorname{Br}(1)$ & $2.582(2)$ & $\mathrm{Sb}(1)-\mathrm{C}(10)$ & $2.143(5)$ & $\mathrm{Sb}(1)-\mathrm{C}(10)$ & $2.089(4)$ \\
\hline $\mathrm{Sb}(1)-\operatorname{Br}(2)$ & $2.502(2)$ & $\mathrm{Sb}(1)-\mathrm{C}(16)$ & $2.143(5)$ & $\mathrm{Sb}(1)-\mathrm{C}(16)$ & $2.132(6)$ \\
\hline $\mathrm{Sb}(1)-\operatorname{Br}(3)$ & $2.589(2)$ & $\operatorname{Sb}(1) \cdots \mathrm{N}(1)$ & $2.623(4)$ & $\operatorname{Sb}(1)-\operatorname{Br}(1)$ & $2.6207(11)$ \\
\hline $\mathrm{Sb}(1)-\operatorname{Br}(4)$ & $2.545(2)$ & $\mathrm{Sb}(1)-\mathrm{Br}(1)$ & $2.6339(6)$ & $\operatorname{Sb}(1)-\operatorname{Br}(2)$ & $2.6257(12)$ \\
\hline $\mathrm{Sb}(1) \cdots \mathrm{N}(1)$ & $2.347(7)$ & $\mathrm{Sb}(1)-\mathrm{Br}(2)$ & $2.6412(6)$ & & \\
\hline $\mathrm{C}(1)-\mathrm{Sb}(1) \cdots \mathrm{N}(1)$ & $78.7(3)$ & $\operatorname{Br}(1)-\mathrm{Sb}(1)-\mathrm{Br}(2)$ & $174.41(2)$ & $\operatorname{Br}(1)-\mathrm{Sb}(1)-\mathrm{Br}(2)$ & $172.89(3)$ \\
\hline $\operatorname{Br}(1)-\mathrm{Sb}(1) \cdots \mathrm{N}(1)$ & $86.14(17)$ & $\mathrm{C}(1)-\mathrm{Sb}(1)-\mathrm{C}(10)$ & $102.43(19)$ & $\mathrm{C}(1)-\mathrm{Sb}(1)-\mathrm{C}(10)$ & $120.6(2)$ \\
\hline $\operatorname{Br}(2)-\mathrm{Sb}(1) \cdots \mathrm{N}(1)$ & $87.77(18)$ & $\mathrm{C}(10)-\mathrm{Sb}(1)-\mathrm{C}(16)$ & $98.62(18)$ & $\mathrm{C}(10)-\mathrm{Sb}(1)-\mathrm{C}(16)$ & $115.1(2)$ \\
\hline $\operatorname{Br}(3)-\mathrm{Sb}(1) \cdots \mathrm{N}(1)$ & $96.31(17)$ & $\mathrm{C}(1)-\mathrm{Sb}(1)-\mathrm{C}(16)$ & $158.89(18)$ & $\mathrm{C}(1)-\mathrm{Sb}(1)-\mathrm{C}(16)$ & $124.3(2)$ \\
\hline $\operatorname{Br}(4)-\operatorname{Sb}(1) \cdots N(1)$ & $174.65(18)$ & $\mathrm{C}(1)-\mathrm{Sb}(1) \cdots \mathrm{N}(1)$ & $72.25(15)$ & $\mathrm{C}(1)-\mathrm{Sb}(1)-\mathrm{Br}(1)$ & $87.34(18)$ \\
\hline $\mathrm{C}(1)-\mathrm{Sb}(1)-\mathrm{Br}(1)$ & $93.0(2)$ & $\mathrm{C}(10)-\mathrm{Sb}(1) \cdots \mathrm{N}(1)$ & $173.71(16)$ & $\mathrm{C}(10)-\mathrm{Sb}(1)-\mathrm{Br}(1)$ & $88.55(17)$ \\
\hline $\mathrm{C}(1)-\mathrm{Sb}(1)-\mathrm{Br}(2)$ & $166.1(2)$ & $\mathrm{C}(16)-\mathrm{Sb}(1) \cdots \mathrm{N}(1)$ & $86.64(15)$ & $\mathrm{C}(16)-\mathrm{Sb}(1)-\mathrm{Br}(1)$ & $93.3(2)$ \\
\hline $\mathrm{C}(1)-\mathrm{Sb}(1)-\mathrm{Br}(3)$ & $90.6(2)$ & $\operatorname{Br}(1)-\mathrm{Sb}(1) \cdots \mathrm{N}(1)$ & $91.56(8)$ & $\mathrm{C}(1)-\mathrm{Sb}(1)-\mathrm{Br}(2)$ & $87.57(18)$ \\
\hline $\mathrm{C}(1)-\mathrm{Sb}(1)-\mathrm{Br}(4)$ & $98.9(2)$ & $\operatorname{Br}(2)-\mathrm{Sb}(1) \cdots \mathrm{N}(1)$ & $83.98(8)$ & $\mathrm{C}(10)-\mathrm{Sb}(1)-\mathrm{Br}(2)$ & $89.77(17)$ \\
\hline $\operatorname{Br}(1)-\mathrm{Sb}(1)-\mathrm{Br}(2)$ & $89.34(5)$ & $\mathrm{C}(1)-\mathrm{Sb}(1)-\mathrm{Br}(1)$ & $88.64(12)$ & $\mathrm{C}(16)-\mathrm{Sb}(1)-\mathrm{Br}(2)$ & $93.7(2)$ \\
\hline $\mathrm{Br}(1)-\mathrm{Sb}(1)-\mathrm{Br}(3)$ & $175.95(4)$ & $\mathrm{C}(10)-\mathrm{Sb}(1)-\mathrm{Br}(1)$ & $91.67(14)$ & & \\
\hline $\operatorname{Br}(1)-\mathrm{Sb}(1)-\mathrm{Br}(4)$ & $89.24(4)$ & $\mathrm{C}(16)-\mathrm{Sb}(1)-\mathrm{Br}(1)$ & $92.30(13)$ & & \\
\hline $\operatorname{Br}(2)-\mathrm{Sb}(1)-\mathrm{Br}(3)$ & $87.53(5)$ & $\mathrm{C}(1)-\mathrm{Sb}(1)-\mathrm{Br}(2)$ & $86.78(12)$ & & \\
\hline $\operatorname{Br}(2)-\mathrm{Sb}(1)-\mathrm{Br}(4)$ & $94.88(4)$ & $\mathrm{C}(10)-\mathrm{Sb}(1)-\mathrm{Br}(2)$ & $92.45(14)$ & & \\
\hline $\operatorname{Br}(3)-\mathrm{Sb}(1)-\mathrm{Br}(4)$ & $88.46(4)$ & $\mathrm{C}(16)-\mathrm{Sb}(1)-\mathrm{Br}(2)$ & $90.82(13)$ & & \\
\hline
\end{tabular}

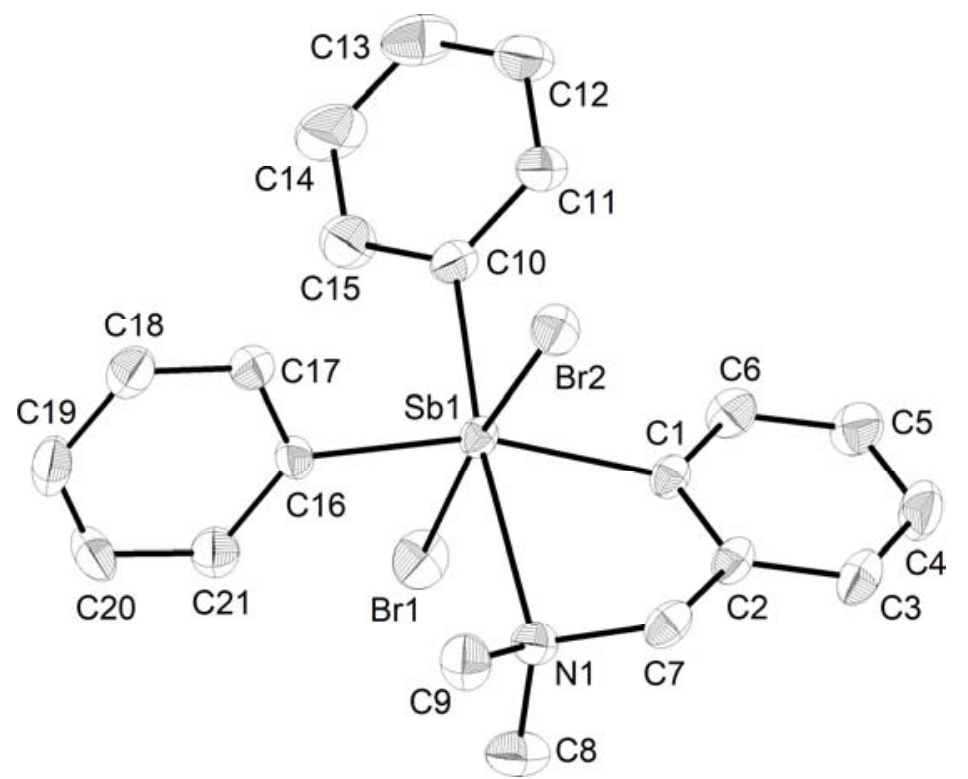

Fig. 2 - Thermal ellipsoids (30\% probability) representation of $S_{N}, A_{S b}-2$. Hydrogen atoms were omitted for clarity. 


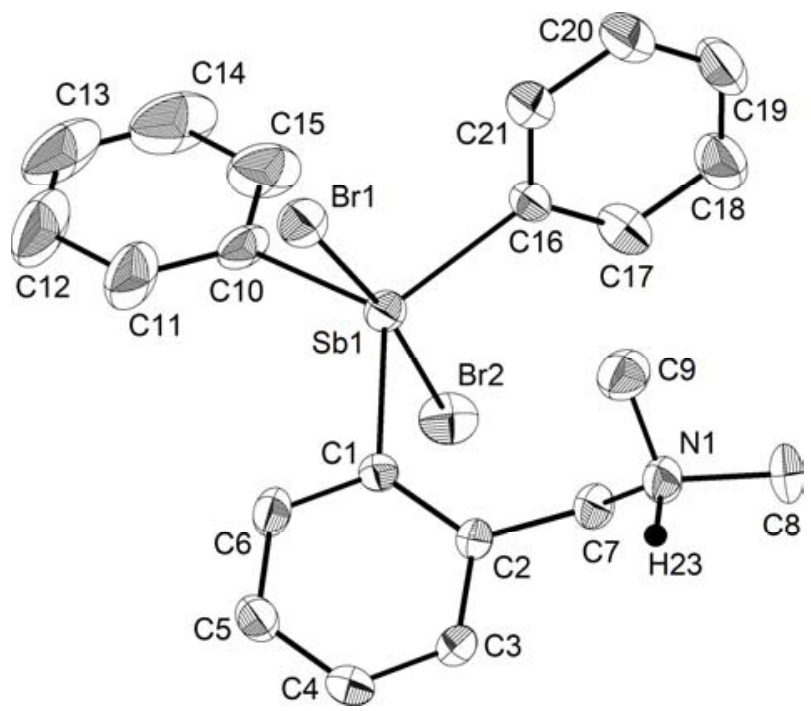

Fig. 3 - Thermal ellipsoids ( $30 \%$ probability) representation of the cation in $3 \cdot \mathrm{CHCl}_{3} \cdot \mathrm{CHCl}_{3}$ and hydrogen atoms, except that attached to nitrogen, were omitted for clarity.

\section{DISCUSSION}

\section{Spectroscopy}

The ${ }^{1} \mathrm{H}$ and ${ }^{13} \mathrm{C}\left\{{ }^{1} \mathrm{H}\right\}$ NMR spectra of $\mathbf{1}$ and $\mathbf{2}$ confirmed the purity of the two species. No evidence for the existence of an intramolecular $\mathrm{N} \rightarrow \mathrm{Sb}$ interaction in solution could be ruled out from the aliphatic region of the room temperature ${ }^{1} \mathrm{H}$ NMR spectra, which show, for both compounds, singlet resonances for the $\mathrm{CH}_{2}$ and the $\mathrm{CH}_{3}$ protons, respectively. For compound 2 the NMR spectra indicate clearly that the two phenyl groups attached to antimony are non-equivalent in solution. In the ${ }^{1} \mathrm{H}$ NMR spectrum two different multiplet resonances in a $1: 1$ molar ratio are present at $\delta$ 7.85-7.94 and 8.36-8.48 ppm, respectively, and they were assigned to the hydrogen atoms in ortho positions of the two phenyl groups, one of them in trans position to the intramolecularly coordinated nitrogen, and the other one in cis position. In the ${ }^{13} \mathrm{C}\left\{{ }^{1} \mathrm{H}\right\}$ NMR spectrum not all $\mathrm{C}_{6} \mathrm{H}_{5}$ carbons give separate resonances, but two different $C_{6} \mathrm{H}_{5}$-ipso resonances could be unambiguously identified at $\delta 141.74$ and $146.27 \mathrm{ppm}$.

Crystal and molecular structure of [2- $\left.\left(\mathrm{Me}_{2} \mathrm{NCH}_{2}\right) \mathrm{C}_{6} \mathrm{H}_{4}\right] \mathrm{SbBr}_{4}(\mathbf{1})$, [2- $\left.\left(\mathrm{Me}_{2} \mathrm{NCH}_{2}\right) \mathrm{C}_{6} \mathrm{H}_{4}\right] \mathrm{Ph}_{2} \mathrm{SbBr}_{2}(2)$ and [ $[2-$ $\left.\left.\left(\mathrm{Me}_{2} \mathrm{NH}^{+} \mathrm{CH}_{2}\right) \mathrm{C}_{6} \mathrm{H}_{4}\right\} \mathrm{Ph}_{2} \mathrm{SbBr}_{2}\right] \mathrm{Br}^{-} \cdot \mathrm{CHCl}_{3}\left(\mathbf{3} \cdot \mathrm{CHCl}_{3}\right)$

In compounds $\mathbf{1}$ and $\mathbf{2}$ the nitrogen atom in the pendant arm is intramolecularly coordinated to antimony, thus resulting in $12-S b-6$ hypercoordinated species, ${ }^{16}$ with a distorted octahedral coordination geometry around antimony. In both compounds, the $\mathrm{N} \rightarrow \mathrm{Sb}$ intramolecular interactions $(\mathrm{N} 1 \rightarrow \mathrm{Sb} 12.347(7) \AA$ in 1 and 2.623(4) $\AA$ in 2) are stronger than in $\left[2-\left(\mathrm{Me}_{2} \mathrm{NCH}_{2}\right) \mathrm{C}_{6} \mathrm{H}_{4}\right] \mathrm{Ph}_{2} \mathrm{Sb} \quad(2.848(4) \quad \AA)^{15 \mathrm{a}}$ and much shorter than the sum of the van der Waals radii of the two elements $\left(\Sigma \mathrm{r}_{\mathrm{vdW}}(\mathrm{N}, \mathrm{Sb}) 3.55 \AA^{17}\right)$. Moreover, the $\mathrm{N} \rightarrow \mathrm{Sb}$ intramolecular coordination induces planar chirality, thus resulting in a nonplanar $\mathrm{SbC}_{3} \mathrm{~N}$ ring, folded about the $\mathrm{Sb} 1 \cdots \mathrm{C} 7$ imaginary axis and, as a consequence, the two compounds crystalize as a mixture of $R$ and $S$ isomers. In addition, the two phenyl groups in $\mathbf{2}$ became non-equivalent as a result of the $\mathrm{N} \rightarrow \mathrm{Sb}$ intramolecular interaction, one of them placed in equatorial and the other one in axial position, trans to nitrogen, thus inducing chirality to antimony. In this way, compound $\mathbf{2}$ crystalizes as a racemic mixture of $R_{N}, C_{S b}$ and $S_{N}, A_{S b}$ isomers. ${ }^{18}$ While 2 has a monomeric structure, the molecules of $\mathbf{1}$ are associated by weak $\mathrm{Br} \cdots \mathrm{H}$ hydrogen bonding

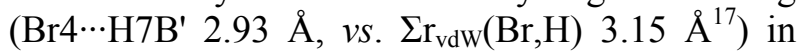
the crystal (Figure 4).

In the cation of $\mathbf{3} \cdot \mathrm{CHCl}_{3}$ (Figure 3 ) antimony has a distorted trigonal bipyramidal coordination geometry, with the bromine atoms in apices $\left(\mathrm{Br}-\mathrm{Sb}-\mathrm{Br} 172.89(3)^{\circ}\right)$. The nitrogen atom in the pendant arm is protonated and thus it is not coordinated to the metal centre. Besides the electrostatic interactions, in the crystal of $\mathbf{3} \cdot \mathrm{CHCl}_{3}$ each $\mathrm{Br}^{-}$anion is involved in weak $\mathrm{Br}{ }^{\cdots} \mathrm{H}$ contacts with hydrogen atoms of two neighbouring

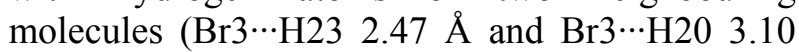
$\AA)$, which result in a chain-like polymeric association (Figure 5). The solvent molecule is not involved in any intermolecular interactions. 


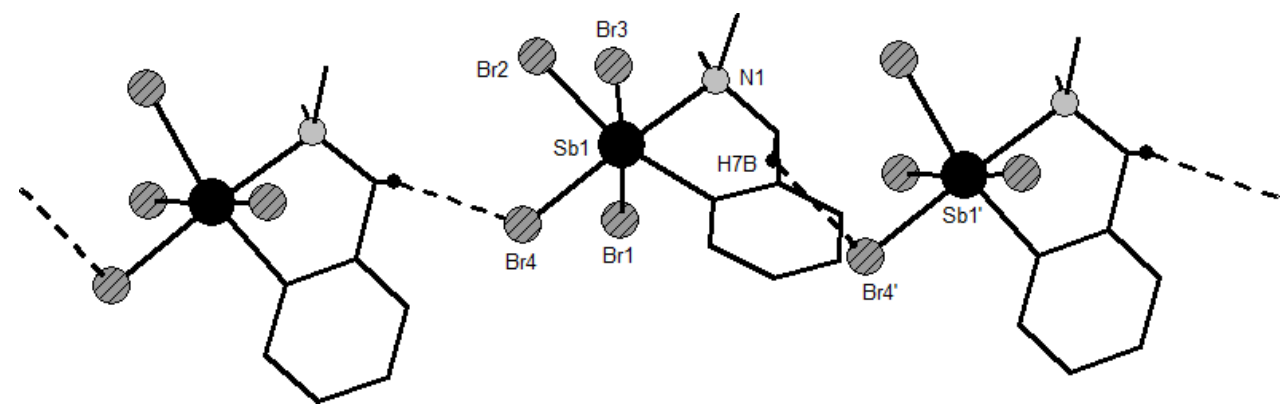

Fig. 4 - Polymeric association in 1. Hydrogen atoms not involved in $\mathrm{H} \cdots \mathrm{Br}$ contacts were omitted for clarity. Symmetry equivalent positions $1 / 2+x, 3 / 2-y,-1 / 2+z$ are given by "prime".

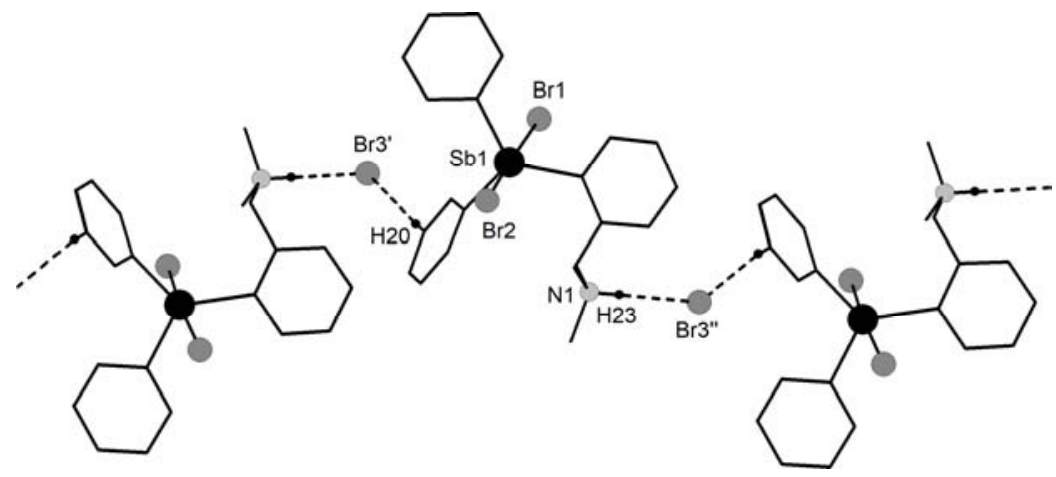

Fig. 5 - Cation-anion association in the crystal of $3 \cdot \mathrm{CHCl}_{3}$. Hydrogen atoms not involved in $\mathrm{H} \cdots \mathrm{Br}$ cation - anion contacts, as well as $\mathrm{CHCl}_{3}$, were omitted for clarity. Symmetry equivalent positions $3 / 2-x,-1 / 2+y, 1 / 2-z$ and $x,-1+y, z$ are given by "prime" and "second", respectively.

\section{EXPERIMENTAL}

The starting organoantimony(III) materials were prepared according to literature procedures: $\left[2-\left(\mathrm{Me}_{2} \mathrm{NCH}_{2}\right) \mathrm{C}_{6} \mathrm{H}_{4}\right] \mathrm{SbBr}_{2},{ }^{13}$ and $\left[2-\left(\mathrm{Me}_{2} \mathrm{NCH}_{2}\right) \mathrm{C}_{6} \mathrm{H}_{4}\right] \mathrm{Ph}_{2} \mathrm{Sb}{ }^{15 \mathrm{a}}$ Elemental analyses were performed on a Flash EA 1112 analyzer. Melting points were measured on an Electrothermal 9200 apparatus and are not corrected. ${ }^{1} \mathrm{H}$ and ${ }^{13} \mathrm{C}\left\{{ }^{1} \mathrm{H}\right\}$ NMR spectra were recorded on a Bruker Avance DRX 300 or a Bruker Avance III 400 instruments. The chemical shifts are reported in $\delta$ units (ppm) relative to TMS (ref. $\mathrm{CHCl}_{3}:{ }^{1} \mathrm{H} 7.26 \mathrm{ppm}$ and ${ }^{13} \mathrm{C} 77.16 \mathrm{ppm}$ ) and they were assigned based on 2D NMR experiments (COSY, HSQC and HMBC) and are given according to the numbering depicted in Scheme 1. The NMR spectra were processed using the MestReC and MestReNova software. ${ }^{19}$<smiles>CN(C)Cc1ccccc1S</smiles>

Scheme 1

\section{Synthesis of [2-( $\left.\mathrm{Me}_{2} \mathrm{NCH}_{2}\right) \mathrm{C}_{6} \mathrm{H}_{4} / \mathrm{SbBr}_{4}(1)$}

To a suspension of $\left[2-\left(\mathrm{Me}_{2} \mathrm{NCH}_{2}\right) \mathrm{C}_{6} \mathrm{H}_{4}\right] \mathrm{SbBr}_{2}(0.72 \mathrm{~g}$, $1.73 \mathrm{mmol})$ in toluene $(10 \mathrm{~mL})$ was added a solution of bromine $(0.28 \mathrm{~g}, 1.73 \mathrm{mmol})$ in toluene $(20 \mathrm{~mL})$ at $-20^{\circ} \mathrm{C}$ and the reaction mixture was left under stirring for two hours. From the red solution toluene was removed under reduced pressure. The remained yellow solid was washed with hexane $(2 \times 10 \mathrm{~mL})$ and dried under reduced pressure. Yield: $0.88 \mathrm{~g}$ (88\%). M.p. $173-175{ }^{\circ} \mathrm{C}$ (dec.). Elemental analysis calcd. for $\mathrm{C}_{9} \mathrm{H}_{12} \mathrm{Br}_{4} \mathrm{NSb}(\mathrm{MW}=575.58): \mathrm{C}, 18.78 ; \mathrm{H}, 2.10 ; \mathrm{N}, 2.43 \%$. Found $\mathrm{C}, 18.92 ; \mathrm{H}, 2.12 ; \mathrm{N}, 2.48 \% .{ }^{1} \mathrm{H} \mathrm{NMR}\left(\mathrm{CDCl}_{3}, 400.13\right.$ $\mathrm{MHz}): \delta 3.01\left(\mathrm{~s}, 6 \mathrm{H}, \mathrm{N}\left(\mathrm{CH}_{3}\right)_{2}\right), 4.23\left(\mathrm{~s}, 2 \mathrm{H}, \mathrm{CH}_{2} \mathrm{~N}\right), 7.07(\mathrm{~d}$, $\left.1 \mathrm{H}, \mathrm{H}-3,{ }^{3} \mathrm{~J}_{\mathrm{HH}} 7.4 \mathrm{~Hz}\right), 7.42\left(\mathrm{t}, 1 \mathrm{H}, \mathrm{H}-4,{ }^{3} \mathrm{~J}_{\mathrm{HH}} 7.4 \mathrm{~Hz}\right), 7.53(\mathrm{t}$, $\left.1 \mathrm{H}, \mathrm{H}-5,{ }^{3} \mathrm{~J}_{\mathrm{HH}} 7.3 \mathrm{~Hz}\right), 7.78\left(\mathrm{~d}, 1 \mathrm{H}, \mathrm{H}-6,{ }^{3} \mathrm{~J}_{\mathrm{HH}} 8.1 \mathrm{~Hz}\right) .{ }^{13} \mathrm{C}\left\{{ }^{1} \mathrm{H}\right\}$ NMR $\left.\left(\mathrm{CDCl}_{3}, 100.61 \mathrm{MHz}\right): \quad \delta \quad 47.89 \quad \mathrm{~N}\left(\mathrm{CH}_{3}\right)_{2}\right), \quad 59.37$ $\left(\mathrm{CH}_{2} \mathrm{~N}\right), 124.97\left(\mathrm{C}_{6} \mathrm{H}_{4}, \mathrm{C}-6\right), 126.98\left(\mathrm{C}_{6} \mathrm{H}_{4}, \mathrm{C}-3\right), 127.48$ $\left(\mathrm{C}_{6} \mathrm{H}_{4}, \mathrm{C}-2\right), 130.20\left(\mathrm{C}_{6} \mathrm{H}_{4}, \mathrm{C}-5\right), 132.32\left(\mathrm{C}_{6} \mathrm{H}_{4}, \mathrm{C}-4\right), 154.49$ $\left(\mathrm{C}_{6} \mathrm{H}_{4}, \mathrm{C}-1\right)$.

\section{Synthesis of [2-( $\left.\left.\mathrm{Me}_{2} \mathrm{NCH}_{2}\right) \mathrm{C}_{6} \mathrm{H}_{4}\right] \mathrm{Ph}_{2} \mathrm{SbBr}_{2}$ (2)}

To a solution of [2-( $\left.\left.\mathrm{Me}_{2} \mathrm{NCH}_{2}\right) \mathrm{C}_{6} \mathrm{H}_{4}\right] \mathrm{Ph}_{2} \mathrm{Sb}(4.27 \mathrm{~g}, 10$ $\mathrm{mmol})$ in petroleum ether $(330 \mathrm{~mL})$ was added dropwise a solution of bromine $(1.66 \mathrm{~g}, 10 \mathrm{mmol})$ in petroleum ether $(20$ $\mathrm{mL}$ ) at $0{ }^{\circ} \mathrm{C}$ and the reaction mixture was left under stirring for 72 hours after reaching the room temperature. The solvent was removed at reduced pressure when the title compound resulted as a colourless solid. M.p. $216-218{ }^{\circ} \mathrm{C}$. Yield $4.63 \mathrm{~g}(78 \%)$. Elemental analysis calcd. for $\mathrm{C}_{21} \mathrm{H}_{22} \mathrm{Br}_{2} \mathrm{NSb}(\mathrm{MW}=569.98)$ : C, 44.25; H, 3.89; N, 2.46\%. Found C, 44.48; H, 4.02; N, $2.51 \% .{ }^{1} \mathrm{H} \mathrm{NMR}\left(300 \mathrm{MHz}, \mathrm{CDCl}_{3}\right): \delta 2.29\left(\mathrm{~s}, 6 \mathrm{H}, \mathrm{N}\left(\mathrm{CH}_{3}\right)_{2}\right)$, $3.94\left(\mathrm{~s}, 2 \mathrm{H}, \mathrm{CH}_{2} \mathrm{~N}\right), 7.23\left(\mathrm{~d}, 1 \mathrm{H}, \mathrm{C}_{6} H_{4},{ }^{3} \mathrm{~J}_{\mathrm{HH}} 6.38 \mathrm{~Hz}\right), 7.33-$ $7.53\left(\mathrm{~m}, 2 \mathrm{H}, \mathrm{C}_{6} H_{4}+6 \mathrm{H}, \mathrm{C}_{6} H_{5}\right.$-meta + para $), 7.60\left(\mathrm{~d}, 1 \mathrm{H}, \mathrm{C}_{6} H_{4}\right.$, $\left.{ }^{3} \mathrm{~J}_{\mathrm{HH}} 6.38 \mathrm{~Hz}\right), 7.85-7.94\left(\mathrm{~m}, 2 \mathrm{H}, \mathrm{C}_{6} H_{5}\right.$-ortho $), 8.36-8.48(\mathrm{~m}$, $2 \mathrm{H}, \mathrm{C}_{6} H_{5}$-ortho $) .{ }^{13} \mathrm{C}\left\{{ }^{1} \mathrm{H}\right\}$ NMR $\left(75.47 \mathrm{MHz}, \mathrm{CDCl}_{3}\right): \delta 45.93$ $\left(\mathrm{s}, \mathrm{N}\left(\mathrm{CH}_{3}\right)_{2}\right), 61.39\left(\mathrm{~s}, \mathrm{CH}_{2} \mathrm{~N}\right), 128.44\left(\mathrm{C}_{6} \mathrm{H}_{5}\right), 128.72\left(\mathrm{C}_{6} \mathrm{H}_{5}\right)$, $128.86\left(\mathrm{C}_{6} \mathrm{H}_{4}\right), 129.42\left(\mathrm{C}_{6} \mathrm{H}_{4}, \mathrm{C}-3\right), 129.99\left(\mathrm{C}_{6} \mathrm{H}_{4}\right), 130.36$ $\left(\mathrm{C}_{6} \mathrm{H}_{5}\right), 130.70\left(\mathrm{C}_{6} \mathrm{H}_{4}, \mathrm{C}-6\right), 133.18 \quad\left(\mathrm{C}_{6} \mathrm{H}_{5}\right.$-ortho $), 134.77$ $\left(\mathrm{C}_{6} \mathrm{H}_{4}, \mathrm{C}-2\right), 135.44\left(\mathrm{C}_{6} \mathrm{H}_{5}\right.$-ortho $), 141.74\left(\mathrm{C}_{6} \mathrm{H}_{5}\right.$-ipso $), 146.27$ $\left(\mathrm{C}_{6} \mathrm{H}_{5}\right.$-ipso $), 148.68\left(\mathrm{C}_{6} \mathrm{H}_{4}, \mathrm{C}-1\right)$. 
Table 2

Crystal and structure refinement data for compounds $\mathbf{1 , 2}$ and $\mathbf{3} \cdot \mathrm{CHCl}_{3}$

\begin{tabular}{|c|c|c|c|}
\hline & 1 & 2 & 3. $\mathrm{CHCl}_{3}$ \\
\hline Empirical formula & $\mathrm{C}_{9} \mathrm{H}_{12} \mathrm{Br}_{4} \mathrm{NSb}$ & $\mathrm{C}_{21} \mathrm{H}_{22} \mathrm{Br}_{2} \mathrm{NSb}$ & $\mathrm{C}_{22} \mathrm{H}_{24} \mathrm{Br}_{3} \mathrm{Cl}_{3} \mathrm{NSb}$ \\
\hline Formula weight, $\mathrm{g} / \mathrm{mol}$ & 575.59 & 569.97 & 770.25 \\
\hline Temperature, $\mathrm{K}$ & 294(2) & $297(2)$ & $297(2)$ \\
\hline Wavelength, $\AA$ & 0.71073 & 0.71073 & 0.71073 \\
\hline Crystal system & Monoclinic & Monoclinic & Monoclinic \\
\hline Space group & $P 2_{1} / n$ & $P 2_{1} / c$ & $P 2_{1} / c$ \\
\hline$a[\AA]$ & $9.486(7)$ & $9.2459(14)$ & $9.717(3)$ \\
\hline$b[\AA]$ & $15.964(11)$ & $13.933(2)$ & $19.049(6)$ \\
\hline$c[\AA]$ & $9.662(7)$ & $16.247(2)$ & $14.910(5)$ \\
\hline$\alpha\left[^{\circ}\right]$ & 90 & 90 & 90 \\
\hline$\beta\left[^{\circ}\right]$ & $97.113(15)$ & $92.948(3)$ & $98.320(6)$ \\
\hline$\gamma\left[{ }^{\circ}\right]$ & 90 & 90 & 90 \\
\hline Volume, $\AA^{3}$ & $1451.9(18)$ & $2090.2(5)$ & $2730.7(16)$ \\
\hline Z & 4 & 4 & 4 \\
\hline Density (calculated), $\mathrm{g} / \mathrm{cm}^{3}$ & 2.633 & 1.811 & 1.874 \\
\hline Absorption coefficient, $\mathrm{mm}^{-1}$ & 12.879 & 5.147 & 5.704 \\
\hline$F(000)$ & 1056 & 1104 & 1480 \\
\hline Crystal size, $\mathrm{mm}$ & $0.29 \times 0.23 \times 0.21$ & $0.42 \times 0.34 \times 0.14$ & $0.36 \times 0.22 \times 0.14$ \\
\hline$\theta$ range for data collection, ${ }^{\circ}$ & 2.478 to 24.992 & 1.93 to 25.00 & 1.75 to 25.00 \\
\hline Reflections collected & 13109 & 19772 & 19648 \\
\hline Independent reflections & $2553[R($ int $)=0.1045]$ & $3671[R(\mathrm{int})=0.0600]$ & $4811[R(\mathrm{int})=0.0581]$ \\
\hline Completeness to $\theta=25^{\circ}, \%$ & 99.8 & 100 & 99.9 \\
\hline Refinement method & & Full-matrix least-squares on $F^{2}$ & \\
\hline Data / restrains / parameters & $2553 / 0 / 136$ & $3671 / 0 / 228$ & $4811 / 48 / 275$ \\
\hline Goodness-of-fit on $F^{2}$ & 0.974 & 1.074 & 1.098 \\
\hline Final $R$ indices $[I>2 \sigma(I)]$ & $R 1=0.0455, w R 2=0.0948$ & $R 1=0.0391, w R 2=0.0863$ & $R 1=0.0534, w R 2=0.1036$ \\
\hline$R$ indices (all data) & $R 1=0.0657, w R 2=0.1018$ & $R 1=0.0471, w R 2=0.0893$ & $R 1=0.0745, w R 2=0.1103$ \\
\hline Largest diff. peak and hole, e $\cdot \AA^{-3}$ & 1.002 and -1.218 & 0.809 and -0.575 & 0.815 and -0.668 \\
\hline
\end{tabular}




\section{Single-crystal X-ray diffraction studies}

Single crystals of $\mathbf{1}$ and $\mathbf{2}$ were grown by slow diffusion from a mixture of dry solvents, $\mathrm{CH}_{2} \mathrm{Cl}_{2}$ and $n$-hexane $(1: 4$, $\mathrm{v} / \mathrm{v})$. The attempts to grow single crystals of 2 from a mixture of $\mathrm{CHCl}_{3}$ and $n$-hexane $(1: 4, \mathrm{v} / \mathrm{v})$ in open atmosphere resulted in the hydrolysis product $\left[\left\{2-\left(\mathrm{Me}_{2} \mathrm{NH}^{+} \mathrm{CH}_{2}\right) \mathrm{C}_{6} \mathrm{H}_{4}\right\}\right.$ $\left.\mathrm{Ph}_{2} \mathrm{SbBr}_{2}\right] \mathrm{Br}^{-} \cdot \mathrm{CHCl}_{3}\left(3 \cdot \mathrm{CHCl}_{3}\right)$. The data were collected at room temperature on a Bruker SMART APEX CCD diffractometer using graphite-monochromated Mo-Ka radiation $(\lambda=0.71073 \AA)$. The details of the crystal structure determination and refinement are given in Table 2.

The structures were refined with anisotropic thermal parameters. The hydrogen atoms were refined with a riding model and a mutual isotropic thermal parameter. One chlorine atom in $3 \cdot \mathrm{CHCl}_{3}$ is disordered over two positions with 44 and $56 \%$ occupancies, respectively. The structures were solved and refined using the software package SHELX-9 $97^{20}$ and the drawings of the molecular structures were created with the Diamond program. ${ }^{21}$ Short $\mathrm{Br}^{\cdots} \cdot \mathrm{H}$ intermolecular contacts were found with PLATON. ${ }^{22}$

\section{CONCLUSIONS}

The new antimony $(\mathrm{V})$ compounds [2$\left.\left(\mathrm{Me}_{2} \mathrm{NCH}_{2}\right) \mathrm{C}_{6} \mathrm{H}_{4}\right] \mathrm{SbBr}_{4} \quad$ (1) and [2$\left.\left(\mathrm{Me}_{2} \mathrm{NCH}_{2}\right) \mathrm{C}_{6} \mathrm{H}_{4}\right] \mathrm{Ph}_{2} \mathrm{SbBr}_{2}$ (2) were prepared and structurally characterized both in solution and in solid state. An octahedral environment around antimony was evidenced by single-crystal X-ray diffraction studies in both compounds, as a result of a strong $\mathrm{N} \rightarrow \mathrm{Sb}$ interaction. For compound 2 the NMR spectra suggested that the intramolecular coordination is preserved in solution as well. Single-crystals of the ionic species $[\{2-$ $\left.\left.\left(\mathrm{Me}_{2} \mathrm{NH}^{+} \mathrm{CH}_{2}\right) \mathrm{C}_{6} \mathrm{H}_{4}\right\} \mathrm{Ph}_{2} \mathrm{SbBr}_{2}\right] \mathrm{Br}^{-} \cdot \mathrm{CHCl}_{3}$

$\left(3 \cdot \mathrm{CHCl}_{3}\right)$ resulted from the reactions of 2 with traces of $\mathrm{HBr}$ formed in situ. While the crystal of 2 contains independent molecules separated by normal van der Waals distances, the crystals of $\mathbf{1}$ and $3 \cdot \mathrm{CHCl}_{3}$ contain polymeric chains formed by weak $\mathrm{Br} \cdots \mathrm{H}$ contacts.

Acknowledgements. Financial support from National University Research Council of Roumania (Research Project PNIII-ID PCE-0857/2016) is highly acknowledged.

\section{Supplementary material}

CCDC 1960753, 1960754 and 1960755 contain the supplementary crystallographic data for compounds 1, 2, and $\mathbf{3} \cdot \mathrm{CHCl}_{3}$, respectively. These data can be obtained free of charge from The
Cambridge Crystallographic Data Centre via www.ccdc.cam.ac.uk/data_request/cif.

\section{REFERENCES}

1. (a) C. I. Raț, C. Silvestru and H. J. Breunig, Coord. Chem. Rev., 2013, 257, 818. (b) S. K. Hadjikakou, I. I. Ozturk, C. N. Banti, N. Kourkoumelis and N. Hadjiliadisa, J. Inorg. Biochem., 2015, 153, 293. (c) S. Schulz, Coord. Chem. Rev., 2015, 297/298, 49.

2. C. Elschenbroich and A. Salzer, „Organometallics: a Concise Introduction", second edition, Wiley-VCH: Weinheim, 1992.

3. L. Balazs, H. J. Breunig, I. Gheşner and E. Lork, $J$. Organomet. Chem., 2002, 648, 33.

4. J. Vela, P. Sharma, A. Cabrera, C. Álvarez, N. Rosas, S. Hernández and A. Toscano, J. Organomet. Chem., 2001, $634,5$.

5. M. K. Khosa, M. Mazhar, S. Ali, K. C. Molloy, S. Dastgir and F. Shaheen, Turk. J. Chem., 2006, 30, 731.

6. H. Mahalakshmi, V. K. Jain and E. R. T. Tiekink, Main Group Met. Chem., 2001, 24, 391.

7. N. Tan, Y. Chen, S. Yin, R. Qiu, Y. Zhou and C. T. Au, Curr. Org. Chem., 2012, 16, 2462.

8. M. N. Gibbons, M. J. Begley and D. B. Sowerby, J. Organomet. Chem., 1994, 469, C25.

9. (a) T. Tokunaga, H. Seki, S. Yasuike, M. Ikoma, J. Kurita and K. Yamaguchi, Tetrahedron Lett., 2000, 41, 1031. (b) T. Tokunaga, H. Seki, S. Yasuike, M. Ikoma, J. Kurita and K. Yamaguchi, Tetrahedron, 2000, 56, 8833.

10. V. V. Sharutin, V. S. Senchurin, O. K. Sharutina and E. V. Akulova, Russ. J. Gen. Chem., 2008, 78, 2344.

11. K. Ohkata, M. Ohnishi and K.-y. Akiba, Tetrahedron Lett., 1988, 29, 5401.

12. I. Urbanová, R. Jambor, A. Růžička, R. Jirásko and L. Dostál, Dalton Trans., 2014, 43, 505.

13. L. M. Opris, A. Silvestru, C. Silvestru, H. J. Breunig and E. Lork, Dalton Trans., 2003, 4367.

14. A. Toma, C. I. Raţ, A. Silvestru, T. Rüffer, H. Lang and M. Mehring, J. Organomet. Chem., 2013, 696, 2837.

15. (a) D. Copolovici, V. R. Bojan, C. I. Raț, A. Silvestru, H. J. Breunig and C. Silvestru, Dalton Trans., 2010, 39, 6410. (b) D. Copolovici, F. Isaia, H. J. Breunig, C. I. Raț, C. Silvestru, RSC Advances, 2014, 4, 26569.

16. K-y. Akiba (Ed.), "Chemistry of Hypervalent Compounds", Wiley-VCH, New York, 1999.

17. J. Emsley, "Die Elemente", Walter de Gruyter, Berlin, 1994.

18. "Nomenclature of Organic Chemistry", Pergamon Press, Oxford, 1979.

19. MestReC and MestReNova, Mestrelab Research S.L., A Coruna 15706, Santiago de Compostela.

20. (a) G. M. Sheldrik, SHELX-97, Universität Göttingen, Germany, 1997. (b) G. M. Sheldrick, Acta Crystallogr. Sect. A, 2008, 64, 112.

21. K. Brandenburg, DIAMOND-Visual Crystal Structure Information System, Crystal Impact: Postfach 1251, D53002 Bonn, Germany, 2001.

22. A. L. Spek, Acta Cryst. Sect. C, 2015, 71, 9. 
